Correspondence

Peter Kämpfer

peter.kaempfer@agrar.

uni-giessen.de

\title{
Undibacterium pigrum gen. nov., sp. nov., isolated from drinking water
}

\author{
Peter Kämpfer, ${ }^{1}$ Ramon Rosselló-Mora, ${ }^{2}$ Malte Hermansson, ${ }^{3}$ \\ Frank Persson, ${ }^{3}$ Birgit Huber, ${ }^{4}$ Enevold Falsen ${ }^{5}$ and Hans-Jürgen Busse ${ }^{4}$ \\ 'Institut für Angewandte Mikrobiologie, Justus-Liebig-Universität Giessen, D-35392 Giessen, \\ Germany \\ ${ }^{2}$ Institut Mediterrani d'Estudis Avancats (CSIC-UIB), E-07190 Esporles, Mallorca, Spain \\ ${ }^{3}$ Department of Cell and Molecular Biology, Göteborg University, Sweden \\ ${ }^{4}$ Institut für Bakteriologie, Mykologie und Hygiene, Veterinärmedizinische Universität, A-1210 \\ Wien, Austria \\ ${ }^{5}$ Culture Collection University Göteborg, Department of Clinical Bacteriology, S-41346 \\ Göteborg, Sweden
}

Two Gram-negative, rod-shaped, oxidase-positive, non-spore-forming, non-motile bacteria (strains CCUG $49009^{\top}$ and CCUG 49012), both isolated from drinking water, were characterized. On the basis of chemotaxonomic data [major ubiquinone, Q-8; predominant polyamines, putrescine and 2-hydroxyputrescine; major polar lipids, phosphatidylethanolamine, moderate amounts of diphosphatidylglycerol and phosphatidylglycerol and minor amounts of three aminolipids and phosphatidylserine; major fatty acids, $\mathrm{C}_{16: 0}$ and summed feature $3\left(\mathrm{C}_{16: 1} \omega 7 \mathrm{c} / \mathrm{C}_{15: 0}\right.$ iso $\left.\left.2-\mathrm{OH}\right)\right]$ and $16 \mathrm{~S}$ rRNA gene sequence similarities, both strains clearly belong to the family Oxalobacteraceae of the Betaproteobacteria. 16S rRNA gene sequence similarities with members of the most closely related genera of this group (Herminiimonas, Massilia, Duganella, Telluria, Herbaspirillum, Janthinobacterium, Naxibacter and Paucimonas) were less than $96.5 \%$ for both strains. The two strains also shared a relatively low $16 \mathrm{~S}$ rRNA gene sequence similarity (96.8\%). Although phylogenetic analysis based on $16 \mathrm{~S}$ rRNA gene sequence similarities clearly showed that the two organisms formed a separate branch, their phenotypes (including chemotaxonomic features) were hardly distinguishable and showed high similarities to those reported for the most closely related genera. On the basis of DNA-DNA hybridization results, the two strains were shown to represent separate species (sharing only $20 \%$ DNA-DNA relatedness), but they could not be clearly differentiated phenotypically from each other. It is evident that these organisms represent a new genus, Undibacterium gen. nov., with one species, Undibacterium pigrum sp. nov. The type strain of Undibacterium pigrum is strain CCUG $49009^{\top}\left(=\operatorname{CIP} 109318^{\top}\right)$. Strain CCUG 49012 (=CIP 108976) probably represents a second species of this genus, but is described here as a second genomovar of this species because of the lack of differentiating characters.

In recent years, several new taxa have been added to the family Oxalobacteraceae (Garrity et al., 2005). In addition to the genera Oxalobacter, Collimonas, Massilia, Duganella, Janthinobacterium, Herbaspirillum, Oxalicibacterium and Telluria, the genera Naxibacter (Xu et al., 2005) and Herminiimonas (Fernandes et al., 2005) have recently been

Abbreviations: DPG, diphosphatidylglycerol; PE, phosphatidylethanolamine; PG, phosphatidylglycerol; pNA, $p$-nitroanilide; pNP, $p$-nitrophenyl.

The GenBank/EMBL/DDBJ accession numbers for the 16S rRNA gene sequence of strains CCUG $49009^{\top}$ and CCUG 49012 are AM397630 and AM397629. described. The majority of these organisms form yellowish-pigmented colonies on nutrient-rich media such as nutrient agar. However, they show very few phenotypic differences, and their allocation to separate genera is based largely on 16S rRNA gene sequence analyses.

Strains CCUG $49009^{\mathrm{T}}$ and CCUG 49012 were isolated from drinking water on R2A agar (Oxoid) at $22^{\circ} \mathrm{C}$. Both strains showed beige-coloured colonies on R2A agar. Subcultivation was done on R2A agar at $25^{\circ} \mathrm{C}$ for 7 days. On this agar, both organisms were able to grow at $4-30^{\circ} \mathrm{C}$, but not at temperatures above $36^{\circ} \mathrm{C}$. Strain CCUG $49009^{\mathrm{T}}$ was able to 
grow on tryptone soy agar (TSA), nutrient agar and MacConkey agar (all from Oxoid), whereas strain CCUG 49012 was not able to grow on TSA and grew only slowly on nutrient agar.

Gram-staining was performed as described by Gerhardt et al. (1994). Cell morphology was observed under a Zeiss light microscope at $\times 1000$, with cells grown for 7 days at $25^{\circ} \mathrm{C}$ on R2A agar. The $16 \mathrm{~S}$ rRNA gene was analysed as described by Kämpfer et al. (2003). Phylogenetic analysis was performed using the software package MEGA version 2.1 (Kumar et al., 2001) after multiple sequence alignment employing CLUSTAL X (Thompson et al., 1997). The sequenced lengths of the 16S rRNA gene were 1434 and $1442 \mathrm{bp}$, respectively, for strains CCUG $49009^{\mathrm{T}}$ and CCUG 49012. Nucleotide sequence similarities were below $96.5 \%$ with all established species of the genera Herminiimonas, Massilia, Duganella, Telluria, Herbaspirillum, Janthinobacterium, Naxibacter and Paucimonas. The two strains shared a $16 \mathrm{~S}$ rRNA gene similarity of $96.8 \%$. The phylogenetic tree shown in Fig. 1 results from a neighbour-joining reconstruction. A maximum-parsimony tree revealed the same branching (not shown). In all calculations, the two sequences were placed on a separate phylogenetic branch, indicating their independent affiliation.

For quinone and polar lipid analysis, cells of CCUG $49009^{\mathrm{T}}$ and CCUG 49012 were grown on PYE medium (Hauser et al., 2005). The content of respiratory quinones was determined as described previously (Tindall, 1990; Altenburger et al., 1996) but using an HPLC consisting of a JASCO PU 2080 Plus Pump and JASCO UV-2075 Plus UV/Vis detector. In both strains, ubiquinone Q-8 was detected exclusively, which is a characteristic trait of all members of the Betaproteobacteria (Yokota et al., 1992). For polyamine analyses, cells of CCUG $49009^{\mathrm{T}}$ were grown under standardized conditions as described by Busse \& Auling (1988). Because of its very poor growth on PYE medium, strain CCUG 49012, which grew well on R2A, was cultivated in a medium of new composition which consisted of the carbon sources of PYE medium and the salts of R2A, here designated R2-PYE $\left(1^{-1}: 0.75 \mathrm{~g}\right.$ peptone from casein, 0.75 g yeast extract, $0.3 \mathrm{~g} \mathrm{~K}_{2} \mathrm{HPO}_{4}, 0.024 \mathrm{~g} \mathrm{MgSO}_{4}, \mathrm{pH}$ 7.2). In this medium, like in PYE medium, CCUG 49012 showed flocculent growth. This growth characteristic made it impossible to measure the optical density, and it was therefore not possible to determine $70 \%$ of the maximum optical density, as recommended for harvesting of cells to be subjected to polyamine analysis (Busse \& Auling, 1988). In order to obtain biomass from the exponential growth phase, two Erlenmeyer flasks containing identical volumes of R2-PYE were inoculated separately with 0.5 and $3.0 \mathrm{ml}$ of a 2 day culture and growth was followed visually. After 2 days of cultivation at room temperature on a rotary shaker, when cell density was still visibly lower in the low-inoculum flask than in the high-inoculum flask, cells from the former flask were harvested and used for polyamine analysis. Polyamines were analysed as described by Busse \& Auling (1988) and Busse et al. (1997) except that a JASCO PU 2080 Plus pump was employed. Strains CCUG $49009^{\mathrm{T}}$ and CCUG 49012 exhibited polyamine patterns that were in accordance with their affiliation to the Betaproteobacteria (Busse \& Auling,

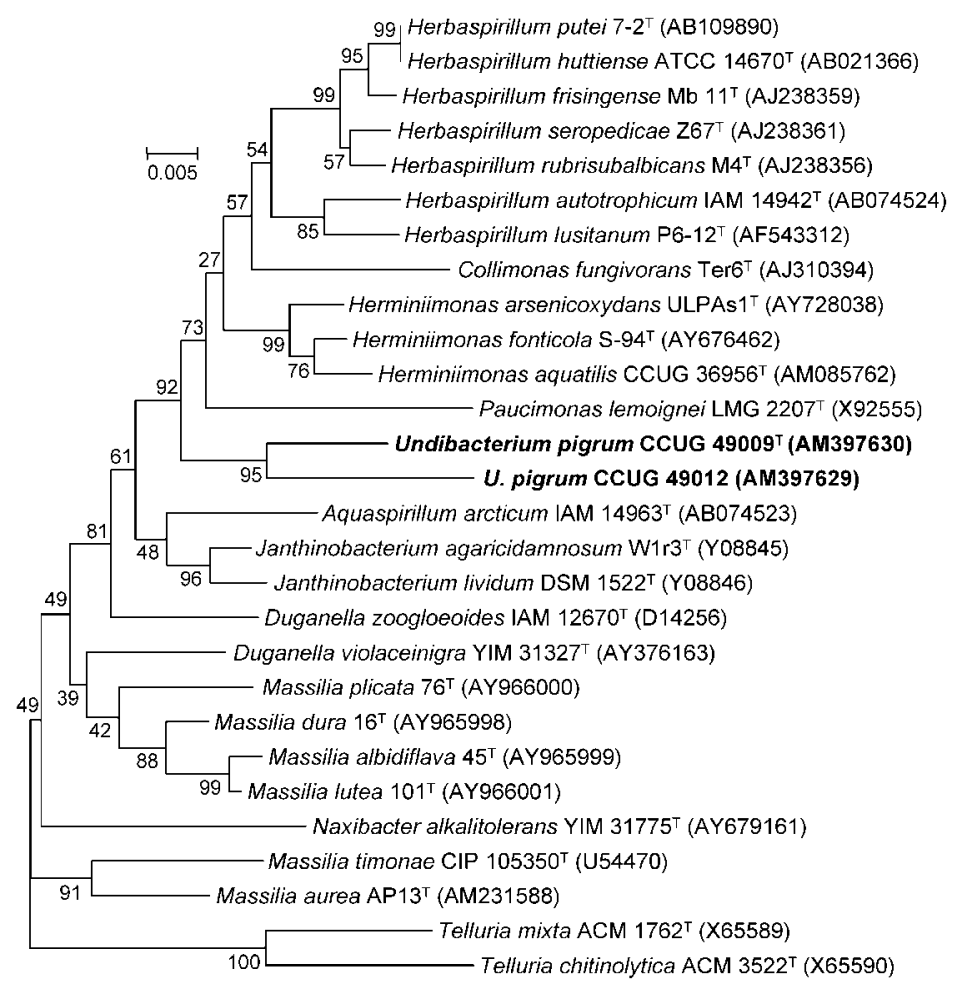

Fig. 1. Phylogenetic analysis based on $16 \mathrm{~S}$ rRNA gene sequences available from the European Molecular Biology Laboratory database (accession numbers are given in parentheses) constructed after multiple alignments of data by CLUSTAL $X$ (Thompson et al., 1997). Distances (distance options according to the Kimura-2 model) and clustering with the neighbour-joining method was performed by using the software package MEGA version 2.1 (Kumar et al., 2001). Bootstrap values based on 1000 replications are listed as percentages at branching points. Bar, 0.005 nucleotide substitutions per nucleotide position. 
1988; Auling et al., 1991; Hamana \& Takeuchi, 1998), consisting of the predominant compounds putrescine [respectively 79.8 and $80.1 \mu \mathrm{mol}$ (g dry weight) ${ }^{-1}$ in strains CCUG $49009^{\mathrm{T}}$ and CCUG 49012] and 2-hydroxyputrescine [39.8 and $44.1 \mu \mathrm{mol}$ (g dry weight $)^{-1}$ ], moderate to minor amounts of spermidine [8.8 and $0.7 \mu \mathrm{mol}(\mathrm{g} \text { dry weight })^{-1}$, minor to trace amounts of spermine $[1.4$ and $<0.1 \mu \mathrm{mol}$ (g dry weight $)^{-1}$ and traces of 1,3-diaminopropane in CCUG $49012\left[<0.1 \mu \mathrm{mol}(\mathrm{g} \text { dry weight })^{-1}\right]$.

The polar lipid patterns of strains CCUG $49009^{\mathrm{T}}$ and CCUG 49012 were almost identical. Both strains contained the predominant lipid phosphatidylethanolamine (PE), moderate amounts of diphosphatidylglycerol (DPG) and phosphatidylglycerol (PG) and minor amounts of three aminolipids and phosphatidylserine (Fig. 2). In a second analysis from independently grown biomass, an additional phospholipid was detected in the extract of CCUG 49012 that showed chromatographic behaviour similar to PE in the first dimension, but the migration distance was almost twice that of PE in the second dimension. Since this finding could not be reproduced, its presence might be related to not highly standardized growth conditions and hence it appears not to be useful for differentiation between the two strains. The lipids PG, PE and DPG have been already reported for other betaproteobacteria, such as species of the Alcaligenaceae and Janthinobacterium and Polaromonas aquatica and Herminiimonas aquatilis (Lincoln et al., 1999; Stolz et al., 2005; Kämpfer et al., 2006a, b, c) and Massilia timonae CCUG $45783^{\mathrm{T}}$, but within a much more complex profile (H.-J. Busse, unpublished results). Thus, polar lipid profiles of newly examined strains consisting of the components

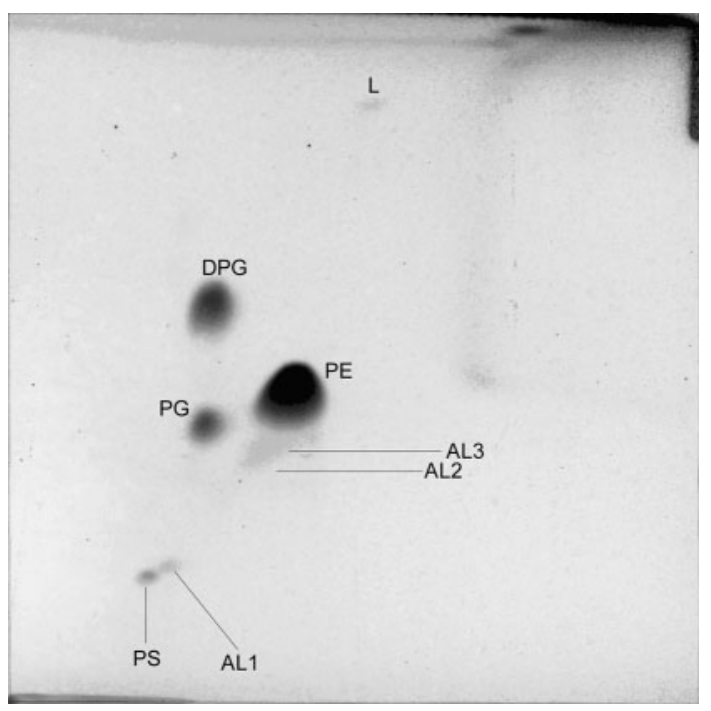

Fig. 2. Two-dimensional thin-layer chromatogram of polar lipids of strain CCUG $49009^{\top}$. DPG, Diphosphatidylglycerol; PE, phosphatidylethanolamine; PG, phosphatidylglycerol; PS, phosphatidylserine; AL1-3, unknown aminolipids; L, unknown polar lipid. detected in CCUG $49009^{\mathrm{T}}$ and CCUG 49012 may indicate a relationship at the genus level, whereas more complex profiles may be indicative of a more distant relationship.

The cellular fatty acid profiles of strains CCUG $49009^{\mathrm{T}}$ and CCUG 49012 are given in detail in Table 1. Because the strains were not able to grow on TSA, they were grown on R2A agar for $48 \mathrm{~h}$ prior to fatty acid analysis. Methods for analysis have been described previously (Kämpfer \& Kroppenstedt, 1996). The major fatty acids were $C_{16: 0}$, summed feature $3\left(\mathrm{C}_{16: 1} \omega 7 c / \mathrm{C}_{15: 0}\right.$ iso $\left.2-\mathrm{OH}\right)$ and $\mathrm{C}_{18: 1} \omega 7 c$. In addition, $\mathrm{C}_{10: 0} 3-\mathrm{OH}$ was the only hydroxylated fatty acid detected. These fatty acids were detected in the type strains of all species studied comparatively under the same conditions (Table 1). The fatty acid $\mathrm{C}_{17: 0}$ cyclo was not detected in strains CCUG $49009^{\mathrm{T}}$ and CCUG 49012, in contrast to Herminiimonas fonticola S-94 ${ }^{\mathrm{T}}$, Telluria mixta CCUG $35206^{\mathrm{T}}$, Janthinobacterium agaricidamnosum CCUG $43140^{\mathrm{T}}$ and Janthinobacterium lividum CCUG $2344^{\mathrm{T}}$, in which this fatty acid accounted for $>15 \%$. This fatty acid profile was also reported for Herminiimonas arsenicoxydans (Muller et al., 2006) and for other Herminiimonas fonticola strains (Fernandes et al., 2005), but not for Herminiimonas aquatilis (Kämpfer et al., 2006b), when grown on TSA (Oxoid) prior to fatty acid extraction. In addition, $\mathrm{C}_{17: 0}$ cyclo has been reported for Naxibacter alkalitolerans (Xu et al., 2005), all Janthinobacterium species and all Herbaspirillum species (Lincoln et al., 1999; Ding \& Yokota, 2004) and Telluria species (P. Kämpfer, unpublished) when grown on TSA (Oxoid) prior to fatty acid extraction. The only hydroxylated fatty acid of strains CCUG $49009^{\mathrm{T}}$ and CCUG 49012 was $\mathrm{C}_{10: 0} 3-\mathrm{OH}$; this hydroxylated fatty acid was found in all comparatively studied strains (Table 1) and has been reported in the fatty acid profiles of Naxibacter (Xu et al., 2005), Herminiimonas (Fernandes et al., 2005; Kämpfer et al., 2006b; Muller et al., 2006), Massilia (La Scola et al., 1998; Lindquist et al., 2003; Zhang et al., 2006), Duganella (Li et al., 2004), Telluria (P. Kämpfer, unpublished) and Paucimonas (Jendrossek, 2001). Additional hydroxylated fatty acids were detected in Telluria mixta CCUG $35206^{\mathrm{T}}$, Janthinobacterium agaricidamnosum CCUG $43140^{\mathrm{T}}$, Janthinobacterium lividum CCUG $2344^{\mathrm{T}}$ and Massilia timonae CCUG $45783^{\mathrm{T}}$ (Table 1). The presence of $\mathrm{C}_{12: 0} 3-\mathrm{OH}$ has been reported for Paucimonas (Jendrossek, 2001), Janthinobacterium (Lincoln et al., 1999) and Herbaspirillum (Lincoln et al., 1999; Ding \& Yokota, 2004) and $\mathrm{C}_{12: 0} 2-\mathrm{OH}$ has been reported to be present in Naxibacter and Duganella (Xu et al., 2005), Janthinobacterium (Lincoln et al., 1999), Herbaspirillum (Lincoln et al., 1999; Ding \& Yokota, 2004) and Massilia timonae (La Scola et al., 1998). The hydroxylated fatty acid $\mathrm{C}_{14: 0} 2-\mathrm{OH}$ was found in this study in Telluria mixta CCUG $35206^{\mathrm{T}}$ and Massilia dura CCUG $52213^{\mathrm{T}}$. This compound has also been reported for Paucimonas, Duganella, Telluria and Massilia (La Scola et al., 1998; Lincoln et al., 1999; Jendrossek, 2001; Li et al., 2004; Zhang et al., 2006).

In conclusion, strains CCUG $49009^{\mathrm{T}}$ and CCUG 49012 can be distinguished from species of the genera Herminiimonas, 
Table 1. Major fatty acids (\%) of the Undibacterium strains and the type strains of selected species of the most closely related genera

Strains: 1, CCUG $49009^{\mathrm{T}}$; 2, CCUG 49012; 3, Duganella zoogloeoides IAM $12670^{\mathrm{T}}$; 4, Herminiimonas fonticola S-94 ${ }^{\mathrm{T}}$; 5, Telluria mixta CCUG $35206^{\mathrm{T}}$; 6, Janthinobacterium agaricidamnosum CCUG $43140^{\mathrm{T}}$; 7, Janthinobacterium lividum CCUG $2344^{\mathrm{T}}$; 8 , Massilia timonae CCUG $45783^{\mathrm{T}}$; 9, Massilia dura CCUG $52213^{\mathrm{T}}$. All strains were grown on $\mathrm{R} 2 \mathrm{~A}$ agar at $25^{\circ} \mathrm{C}$ for $48 \mathrm{~h}$ prior to fatty acid analysis. For unsaturated fatty acids, the position of the double bond is located by counting from the methyl $(\omega)$ end of the carbon chain; cis isomers are indicated by the suffix $c$.

\begin{tabular}{|c|c|c|c|c|c|c|c|c|c|}
\hline Fatty acid & 1 & 2 & 3 & 4 & 5 & 6 & 7 & 8 & 9 \\
\hline \multicolumn{10}{|l|}{ Saturated fatty acids } \\
\hline $\mathrm{C}_{10: 0}$ & 1.0 & 3.0 & 0.6 & & 0.4 & 1.3 & 0.4 & 0.4 & 0.3 \\
\hline $\mathrm{C}_{12: 0}$ & 5.3 & 3.2 & 5.8 & & 3.1 & 3.0 & 3.9 & 3.7 & 6.8 \\
\hline $\mathrm{C}_{14: 0}$ & 1.5 & 0.8 & 0.8 & 4.5 & 1.6 & 0.6 & 0.5 & 0.4 & \\
\hline $\mathrm{C}_{16: 0}$ & 22.6 & 23.2 & 26.0 & 20.3 & 27.8 & 34.8 & 30.6 & 28.7 & 30.7 \\
\hline $\mathrm{C}_{18: 0}$ & & & & & 0.7 & & & & \\
\hline \multicolumn{10}{|c|}{ Unsaturated fatty acids } \\
\hline $\mathrm{C}_{18: 1} \omega 7 c$ & 9.0 & 2.1 & 8.0 & 11.0 & 11.0 & 4.5 & 6.7 & 9.5 & 8.6 \\
\hline \multicolumn{10}{|l|}{ Hydroxy fatty acids } \\
\hline $\mathrm{C}_{10: 0} 3-\mathrm{OH}$ & 4.7 & 5.2 & 8.7 & 7.9 & 6.5 & 7.8 & 5.7 & 5.0 & 7.2 \\
\hline $\mathrm{C}_{12: 0} 2-\mathrm{OH}$ & & & & & & 2.2 & 2.6 & 2.3 & \\
\hline $\mathrm{C}_{14: 0} 2-\mathrm{OH}$ & & & & & 3.6 & & & & 4.3 \\
\hline \multicolumn{10}{|l|}{ Summed features ${ }^{\star}$} \\
\hline Summed feature 3 & 55.7 & 62.5 & 50.0 & 38.0 & 29.4 & 9.7 & 23.8 & 41.2 & 42.1 \\
\hline Summed feature 5 & & & & 1.6 & & & & & \\
\hline \multicolumn{10}{|l|}{ Cyclopropane acids } \\
\hline $\mathrm{C}_{17: 0}$ cyclo & & & & 15.2 & 15.0 & 34.2 & 25.0 & 0.5 & \\
\hline $\mathrm{C}_{19: 0}$ cyclo $\omega 8 c$ & & & & 1.5 & & & & & \\
\hline \multicolumn{10}{|c|}{ Branched-chain fatty acids } \\
\hline $\mathrm{C}_{16: 0}$ iso & & & & & 0.5 & & & & \\
\hline $\mathrm{C}_{19: 0}$ iso & & & & & 0.5 & 0.7 & 0.8 & & \\
\hline
\end{tabular}

${ }^{*}$ Summed features are groups of two or three fatty acids that cannot be separated by GLC with the MIDI system. Summed feature 3 contains $\mathrm{C}_{16: 1} \omega 7 c$ and/or $\mathrm{C}_{15: 0}$ iso 2-OH. Summed feature 5 contains $\mathrm{C}_{18: 2} \omega 6,9 c$ and/or $\mathrm{C}_{18: 0}$ anteiso.

Naxibacter, Janthinobacterium and Telluria and from Duganella violaceinigra by the absence of hydroxylated fatty acids other than $\mathrm{C}_{10: 0} 3-\mathrm{OH}$, by the absence of $\mathrm{C}_{17: 0}$ cyclo and unsaturated fatty acids other than $\mathrm{C}_{16: 1} \omega 7 c$ (in summed feature 3 ) and $\mathrm{C}_{18: 1} \omega 7 \mathrm{c}$. Duganella zoogloeoides has a similar fatty acid pattern (Table 1) but is clearly different on the basis of the physiological characteristics.

Results of the physiological characterization are given in the species description. Methods used were described previously (Kämpfer et al., 1991). Both organisms showed negative results for all carbon substrate utilization tests. Completely negative profiles were not found in a comparative study on the basis of the same method in which the type strains of all species of the genera Naxibacter, Duganella, Herminiimonas, Telluria, Massilia and Janthinobacterium were included.

The $\mathrm{G}+\mathrm{C}$ contents for strains CCUG $49009^{\mathrm{T}}$ and CCUG 49012 were determined as described by Ziemke et al. (1998) and resulted in values of $52.3 \mathrm{~mol} \%$ (SD $1 \mathrm{~mol} \%$ ) and $50.6 \mathrm{~mol} \%$ (SD $1 \mathrm{~mol} \%$ ), respectively. DNA-DNA hybridization experiments were performed with CCUG $49009^{\mathrm{T}}$ and CCUG 49012 using the method described by Ziemke et al. (1998), except that, for nick translation, $2 \mu \mathrm{g}$ DNA was labelled during a $3 \mathrm{~h}$ incubation at $15^{\circ} \mathrm{C}$. Strain CCUG $49009^{\mathrm{T}}$ showed relatively low DNA-DNA relatedness to strain CCUG 49012 (20\%, reciprocal analysis $18 \%$ ).

From the results of $16 \mathrm{~S}$ rRNA gene sequencing, it is evident that strains CCUG $49009^{\mathrm{T}}$ and CCUG 49012 are different from each other and from members of all other genera of the family Oxalobacteraceae. Phenotypic differentiation from all other genera of the family is possible by the combination of growth characteristics, fatty acid and polar lipid profiles and physiological properties.

\section{Description of Undibacterium gen. nov.}

Undibacterium (Un'di.bac.te'ri.um. L. n. unda water; L. neut. n. bacterium rod; N.L. neut. n. Undibacterium a rod of water). 
Cells are non-motile, non-spore-forming rods (approx. $2 \mu \mathrm{m}$ in length). Gram-negative and oxidase-positive, showing an oxidative metabolism. The polyamine pattern consists of the predominant compounds putrescine and 2 -hydroxyputrescine. The quinone system is ubiquinone Q-8 and the polar lipid profile consists of the predominant compound phosphatidylethanolamine with moderate amounts of diphosphatidylglycerol and phosphatidylglycerol. The major fatty acids are $\mathrm{C}_{16: 0}$, summed feature 3 $\left(\mathrm{C}_{16: 1} \omega 7 c / \mathrm{C}_{15: 0}\right.$ iso $\left.2-\mathrm{OH}\right)$ and $\mathrm{C}_{18: 1} \omega 7 c . \mathrm{C}_{10: 0} 3-\mathrm{OH}$ is the only hydroxylated fatty acid detected. $\mathrm{C}_{17: 0}$ cyclo is absent. The $\mathrm{G}+\mathrm{C}$ content of the type strain of the type species is $52.3 \mathrm{~mol} \%$. The type species is Undibacterium pigrum.

\section{Description of Undibacterium pigrum sp. nov.}

Undibacterium pigrum (pig'rum. L. neut. adj. pigrum inactive).

Shares all characteristics listed in the genus description. Polyamine pattern, quinone system, polar lipid profile and fatty acid patterns are those listed in the genus description. Additionally, phosphatidylserine and three aminolipids are present in the polar lipid profile. Good growth occurs on R2A agar. No growth on TSA, nutrient agar or MacConkey agar at $25-30^{\circ} \mathrm{C}$. Beige, translucent and shiny colonies with entire edges form within $24 \mathrm{~h}$, with a diameter of approximately $2 \mathrm{~mm}$. L-Alanine $p$-nitroanilide (pNA) is hydrolysed on the basis of the method described by Kämpfer et al. (1991). The following compounds are not hydrolysed: $p$-nitrophenyl (pNP) $\beta$-D-galactopyranoside, pNP $\beta$-Dglucuronide, $\mathrm{pNP} \alpha$-D-glucopyranoside, $\mathrm{pNP} \beta$-D-glucopyranoside, $\mathrm{pNP} \beta$-D-xylopyranoside, bis-pNP phosphate, bis-pNP phenylphosphonate, bis-pNP phosphorylcholine, $\mathrm{L}$-aniline pNA, $\gamma$-L-glutamate $\mathrm{pNA}$ and L-proline pNA. The following compounds are not used as sole sources of carbon: D-gluconate, acetate, propionate, cis-aconitate, trans-aconitate, 4-aminobutyrate, citrate, fumarate, glutarate, DL-3-hydroxybutyrate, itaconate, DL-lactate, L-malate, mesaconate, 2 -oxoglutarate, pyruvate, L-alanine, $\beta$-alanine, L-aspartate, L-leucine, L-ornithine, L-proline, L-serine, $\mathrm{N}$-acetylgalactosamine, $\mathrm{N}$-acetylglucosamine, L-arabinose, L-arbutin, D-cellobiose, D-fructose, D-galactose, D-glucose, maltose, D-mannose, $\alpha$-D-melibiose, L-rhamnose, D-ribose, sucrose, salicin, D-trehalose, D-xylose, adonitol, myoinositol, maltitol, D-mannitol, D-sorbitol, putrescine, adipate, azelate, suberate, L-histidine, L-phenylalanine, Lserine, L-tryptophan, 3-hydroxybenzoate and phenylacetate on the basis of the method described by Kämpfer et al. (1991). No acids are produced from glucose, lactose, sucrose, D-mannitol, dulcitol, salicin, adonitol, inositol, sorbitol, L-arabinose, raffinose, rhamnose, maltose, Dxylose, trehalose, cellobiose, methyl D-glucoside, erythritol, melibiose, D-arabitol or D-mannose.

The type strain is CCUG $49009^{\mathrm{T}}\left(=\mathrm{CIP} 109318^{\mathrm{T}}\right)$, which was isolated by one of us (F. P.) from drinking water on 10 March 2004 in Göteborg, Sweden. A second strain, CCUG 49012 ( = CIP 108976), is also allocated to this genus at present. The $\mathrm{G}+\mathrm{C}$ content of the DNA of this strain is $50.6 \mathrm{~mol} \%$. This strain shares $96.8 \% 16 \mathrm{~S}$ rRNA gene sequence similarity with strain CCUG $49009^{\mathrm{T}}$ and a DNADNA relatedness of $20 \%$. Phenotypically, it is very similar to strain CCUG $49009^{\mathrm{T}}$. The strain represents a genomovar of U. pigrum.

\section{Acknowledgements}

We thank Jean Euzéby for his advice with the nomenclature.

\section{References}

Altenburger, P., Busse, H.-J., Kämpfer, P., Lubitz, W. \& Makristathis, A. (1996). Classification of bacteria isolated from a medieval wall painting. J Biotechnol 47, 39-52.

Auling, G., Busse, H.-J., Pilz, F., Webb, L., Kneifel, H. \& Claus, D. (1991). Rapid differentiation by polyamine analysis of Xanthomonas strains from phytopathogenic pseudomonads and other members of the class Proteobacteria interacting with plants. Int J Syst Bacteriol 41, 223-228.

Busse, H.-J. \& Auling, G. (1988). Polyamine pattern as a chemotaxonomic marker within the Proteobacteria. Syst Appl Microbiol 11, 1-8.

Busse, H.-J., Bunka, S., Hensel, A. \& Lubitz, W. (1997). Discrimination of members of the family Pasteurellaceae based on polyamine patterns. Int J Syst Bacteriol 47, 698-708.

Ding, L. \& Yokota, A. (2004). Proposals of Curvibacter gracilis gen. nov., sp. nov. and Herbaspirillum putei sp. nov. for bacterial strains isolated from well water and reclassification of [Pseudomonas] huttiensis, [Pseudomonas] lanceolata, [Aquaspirillum] delicatum and [Aquaspirillum] autotrophicum as Herbaspirillum huttiense comb. nov., Curvibacter lanceolatus comb. nov., Curvibacter delicatus comb. nov. and Herbaspirillum autotrophicum comb. nov. Int J Syst Evol Microbiol 54, 2223-2230.

Fernandes, C., Rainey, F. A., Nobre, M. F., Pinhal, I., Folhas, F. \& da Costa, M. S. (2005). Herminiimonas fonticola gen. nov. sp. nov., a betaproteobacterium isolated from a source of bottled mineral water. Syst Appl Microbiol 28, 596-603.

Garrity, G. M., Bell, J. A. \& Lilburn, T. (2005). Family II. Oxalobacteraceae fam. nov. In Bergey's Manual of Systematic Bacteriology, 2nd edn, vol. 2, The Proteobacteria, part C, p. 623. Edited by D. J. Brenner, N. R. Krieg, J. T. Staley \& G. M. Garrity. Heidelberg \& New York: Springer.

Gerhardt, P., Murray, R. G. E., Wood, W. A. \& Krieg, N. R. (editors) (1994). Methods for General and Molecular Bacteriology. Washington, DC: American Society for Microbiology.

Hamana, K. \& Takeuchi, M. (1998). Polyamine profiles as chemotaxonomic markers within alpha, beta, gamma, delta, and epsilon subclasses of class Proteobacteria: distribution of 2-hydroxyputrescine and homospermidine. Microbiol Cult Coll 14, 1-14.

Hauser, E., Kämpfer, P. \& Busse, H.-J. (2004). Pseudomonas psychrotolerans sp. nov. Int J Syst Evol Microbiol 54, 1633-1637.

Jendrossek, D. (2001). Transfer of [Pseudomonas] lemoignei, a Gramnegative rod with restricted catabolic capacity, to Paucimonas gen. nov. with one species, Paucimonas lemoignei comb. nov. Int J Syst Evol Microbiol 51, 905-908.

Kämpfer, P. \& Kroppenstedt, R. M. (1996). Numerical analysis of fatty acid patterns of coryneform bacteria and related taxa. Can J Microbiol 42, 989-1005.

Kämpfer, P., Steiof, M. \& Dott, W. (1991). Microbiological characterisation of a fuel-oil contaminated site including numerical identification of heterotrophic water and soil bacteria. Microb Ecol 21, 227-251. 
Kämpfer, P., Dreyer, U., Neef, A., Dott, W. \& Busse, H.-J. (2003). Chryseobacterium defluvii sp. nov., isolated from wastewater. Int J Syst Evol Microbiol 53, 93-97.

Kämpfer, P., Busse, H.-J. \& Falsen, E. (2006a). Polaromonas aquatica sp. nov., isolated from tap water. Int J Syst Evol Microbiol 56, 605-608.

Kämpfer, P., Busse, H.-J. \& Falsen, E. (2006b). Herminiimonas aquatilis sp. nov., a new species from drinking water. Syst Appl Microbiol 29, 287-291.

Kämpfer, P., Denger, K., Cook, A. M., Lee, S.-T., Jäckel, U., Denner, E. B. M. \& Busse, H.-J. (2006c). Castellaniella gen. nov., to accommodate the phylogenetic lineage of Alcaligenes defragrans, and proposal of Castellaniella defragrans gen. nov., comb. nov. and Castellaniella denitrificans sp. nov. Int J Syst Evol Microbiol 56, 815-819.

Kumar, S., Tamura, K., Jakobsen, I.-B. \& Nei, M. (2001). MEGA2: molecular evolutionary genetics analysis software. Bioinformatics $\mathbf{1 7}$ 1244-1245.

La Scola, B., Birtles, R. J., Mallet, M. N. \& Raoult, D. (1998). Massilia timonae gen. nov., sp. nov., isolated from blood of an immunocompromised patient with cerebellar lesions. J Clin Microbiol 36, 2847-2852.

Li, W.-Y., Zhang, Y.-Q., Park, D.-J., Li, C.-T., Xu, L.-H., Kim, C.-J. \& Jiang, C.-L. (2004). Duganella violaceinigra sp. nov., a novel mesophilic bacterium isolated from forest soil. Int J Syst Evol Microbiol 54, 1811-1814.

Lincoln, S. P., Fermor, T. R. \& Tindall, B. J. (1999). Janthinobacterium agaricidamnosum sp. nov., a soft rot pathogen of Agaricus bisporus. Int J Syst Bacteriol 49, 1577-1589.

Lindquist, D., Murrill, D., Burran, W. P., Winans, G., Janda, J. M. \& Probert, W. H. (2003). Characteristics of Massilia timonae and Massilia timonae-like isolates from human patients, with an emended description of the species. J Clin Microbiol 41, 192-196.
Muller, D., Simeonova, D. D., Riegel, P., Mangenot, S., Koechler, S., Lievremont, D., Bertin, P. N. \& Lett, M. C. (2006). Herminiimonas arsenicoxydans sp. nov., a metalloresistant bacterium. Int J Syst Evol Microbiol 56, 1765-1769.

Stolz, A., Bürger, S., Kuhm, A., Kämpfer, P. \& Busse, H.-J. (2005). Pusillimonas noertemannii gen. nov., sp. nov., a new member of the family Alcaligenaceae that degrades substituted salicylates. Int J Syst Evol Microbiol 55, 1077-1081.

Thompson, J. D., Gibson, T. J., Plewniak, F., Jeanmougin, F. \& Higgins, D. G. (1997). The CLUSTAL_X windows interface: flexible strategies for multiple sequence alignment aided by quality analysis tools. Nucleic Acids Res 25, 4876-4882.

Tindall, B. J. (1990). A comparative study of the lipid composition of Halobacterium saccharovorum from various sources. Syst Appl Microbiol 13, 128-130.

Xu, P., Li, W.-J., Tang, S.-K., Zhang, Y.-Q., Chen, G.-Z., Chen, H.-H., Xu, L.-H. \& Jiang, C.-L. (2005). Naxibacter alkalitolerans gen. nov., sp. nov., a novel member of the family 'Oxalobacteraceae' isolated from China. Int J Syst Evol Microbiol 55, 1149-1153.

Yokota, A., Akagawa-Matsushita, M., Hiraishi, A., Katayama, Y., Urakami, T. \& Yamasato, K. (1992). Distribution of quinone systems in microorganisms: Gram-negative eubacteria. Bull Jpn Fed Cult Coll 8, 136-171.

Zhang, Y.-O., Li, W.-J., Zhang, K.-Y., Tian, X.-P., Jiang, Y., Xu, L.-H., Jiang, C.-L. \& Lai, R. (2006). Massilia dura sp. nov., Massilia albidiflava sp. nov., Massilia plicata sp. nov. and Massilia lutea sp. nov., isolated from soils in China. Int J Syst Evol Microbiol 56, 459-463.

Ziemke, F., Höfle, M. G., Lalucat, J. \& Rosselló-Mora, R. (1998). Reclassification of Shewanella putrefaciens Owen's genomic group II as Shewanella baltica sp. nov. Int J Syst Bacteriol 48, 179-186. 